\title{
Prognostic and predictive role of HER2 expression in metastatic gastric cancer in Turkish patients
}

\author{
Mustafa Yıldırım ${ }^{1}$, Arsenal Sezgin ${ }^{2}$, Utku Dönem Dilli ${ }^{3}$, Dinc Süren ${ }^{2}$, Mustafa Yıldız ${ }^{3}$, \\ Vildan Kaya ${ }^{4, *}$, Cem Sezer ${ }^{2}$, Nurullah Bülbüller ${ }^{5}$ \\ ${ }^{1}$ Ministry of Health Batman Regional Government Hospital, Department of Medical Oncology, Batman, Turkey \\ ${ }^{2}$ Antalya Education and Research Hospital, Department of Pathology, Antalya, Turkey \\ ${ }^{3}$ Antalya Education and Research Hospital, Department of Medical Oncology, Antalya, Turkey \\ ${ }^{4}$ Süleyman Demirel University School of Medicine, Department of Radiation Oncology, Isparta, Turkey \\ ${ }^{5}$ Antalya Education and Research Hospital, Department of General Surgery, Antalya, Turkey
}

\section{Email address:}

vildansimsir@yahoo.com(V. Kaya)

\section{To cite this article:}

Mustafa Yıldırım, Arsenal Sezgin, Utku Dönem Dilli, Dinc Süren, Mustafa Yıldız, Vildan Kaya, Cem Sezer, Nurullah Bülbüller. Prognostic and Predictive Role of HER2 Expression in Metastatic Gastric Cancer in Turkish Patients. Cancer Research Journal. Vol. 1, No. 2, 2013, pp. 20-25. doi: 10.11648/j.crj.20130102.12

\begin{abstract}
Background: In this study, we investigate the role of HER2 expression in prediction of the response to treatment combination including dosetaxel, cisplatin and 5-FU which is used in metastatic gastric cancer in Turkish patients. Methods: Patients who were histopathologically diagnosed with metastatic gastric cancer at the Antalya Training and Research Hospital, Clinic of Medical Oncology from 2008 to 2010 were included in this study. Results: IHC assessment identified 4 patients (25\%) 0 / negative, 5 patients $(31.3 \%) 1+/$ negative, 4 patients $(25 \%) 2+/$ suspected, and 3 patients $(18.8 \%) 3+/$ positive. The relationship between HER2 expression and the response using chi-square test was not statistically significant. Conclusions: We believe that identification of patients who will respond to chemoterapy combination is important to prevent complications. The important shortcomings in our study include covering a small number of patients and the use of FISH method. Therefore, we believe that further studies using FISH method with more patients are required to investigate the role of HER2 expression in predicting the response to DCF chemotherapy combination.
\end{abstract}

Keywords: Gastric cancer, Prognosis, HER 2, Chemotherapy, Docetaxel, Cisplatin

\section{Introduction}

HER2 is a member of the epidermal growth factor receptor, which is synthesized by cerb-B2, a protooncogene. Other members of the epidermal growth factor receptors are HER1, HER3 and HER4. HER2 is a transmembrane protein of $185 \mathrm{kD}$ of weight, which has tyrosine kinase activity. When HER2 receptors are activated, they enable the intracellular signal transmission routes and proceed in the differentiation and proliferation pathways of the cell. HER2 gene amplification and overexpression have been identified in many types of cancer, and was primarily studied in breast cancer $[1,2]$. Positive HER2 has been identified in $15-25 \%$ of all cases of breast cancer $[3,4]$. In gastric cancer, HER2 positivity has an extensive variation in literature. Its positivity varies from 6.8 to $34 \%$ by immunohistochemical (IHC) method and from 7.1 to $42.6 \%$ by Fluorescent in situ hybridization method (FISH) [5].

It is known that HER2 expression is a worse prognostic factor in gastric cancer, similar to the breast cancer [6,7]. Metastatic gastric cancer rapidly progresses after identification of the disease. Survival without chemotherapy is $3-5$ months, whereas it can be extended to 8-12 months with combined chemotherapy [8]. Chemotherapy combination of docetaxel, cisplatin and 5FU is frequently used in the metastatic period, and has severe adverse effects. Grade 3-4 toxicity was identified in $75-81 \%$ of the patients. During the term of the treatment, mortality rate in 60 days due to any reason varies from 7 to $9 \%$ [9]. Prediction of the response to this treatment combination will help to protect some patients from complications of the treatment and exitus of some others due to treatment-related reasons. Some clinical and 
laboratory parameters identified during diagnosis may help to predict the prognosis of the disease and the response ratios to the planned treatment. Laboratory parameters can also be used in determining the intensity for treatments to be given to the patients. In this study, we investigated the prognostic role of HER2 expression in metastatic gastric cancer in Turkish patients and its role in predicting the response to DCF chemotherapy involving 24-hour-long constant infusion of docetaxel, cisplatin and 5-FU used in treatment.

\section{Material and Methods}

\subsection{Patient Group}

The study covered patients with metastatic gastric cancer, with performance status of ECOG $0-2$, who have an objectively measurable disease, have sufficient reserve of bone marrow, and have normal hepatic and renal functions, as histopathologically diagnosed at the Antalya Training and Research Hospital, Clinic of Medical Oncology from 2008 to 2010. Patient files were retrospectively reviewed to gather data on the phase of the disease and treatments received. A chemotherapy protocol consisting of 24-hour constant infusion of docetaxel $75 \mathrm{mg} / \mathrm{m} 2 \mathrm{D} 1$, cisplatin 75 $\mathrm{mg} / \mathrm{m} 2 \mathrm{D} 1$ and 5-FU $1000 \mathrm{mg} / \mathrm{m} 2 \mathrm{D} 1-5$ was applied to the patients for at least one cycle. The patients who had an ECOG score of 3 and above were excluded from the study, as well as the patients whose treatments were started at other centers and continued at our clinic.

\subsection{Immunohistochemical Investigation}

All samples were obtained from tissues that were fixated with formalin and buried in paraffin. Paraffin blocks were cut at a thickness of $4 \mu \mathrm{m}$ and were stained with hemotoxylin and eosin for assessment. Following xylene deparaffinization of tissues, which were fixed in formalin in immunohistochemical staining and buried in paraffin, they were gradually rehydrated with ethanol and were processed for HER2.

\subsection{Immunohistochemical Rating}

Expression ratios of positive tumor cells in the samples were evaluated by a pathologist who was not familiar with the clinical properties of the patients. HER2 expressions were evaluated according to membrane staining of cells. The rating system suggested by Hofmann et al. was employed for rating [10]. (Table 1). 2+ cases, which were considered suspicious, were accepted as negative since they could not be processed with FISH.

\subsection{Statistical Analysis}

Statistical analysis was conducted on SPSS 13.0 software program. The relationship between HER2 positive and negative groups was evaluated by using the chi-square test. The relationship of each of the immunohistochemical positive and negative results with survival was investigated using the Kaplan Meier survival analysis. Statistical variations were justified with the Log-rank test. The significant $\mathrm{p}$ value was considered as $<0.05$.

Table 1. Scoring HER 2 expression

\begin{tabular}{ll}
\hline Reactivity Properties & $\begin{array}{l}\text { Score / } \\
\text { Classification }\end{array}$ \\
\hline $\begin{array}{l}\text { Membranous reactivity or no reactivity in }<10 \% \text { of } \\
\text { cells }\end{array}$ & $0 /$ negative \\
$\begin{array}{l}\text { Pale/hardly perceptible membranous activity in }>10 \% \\
\text { of cells; reactivity only in part of the membrane in cells }\end{array}$ & $1+/$ negative \\
$\begin{array}{l}\text { Weak or moderate complete or basolateral membrane } \\
\text { activity in }>10 \% \text { of tumor cells }\end{array}$ & $2+/$ suspected \\
$\begin{array}{l}\text { Moderate or strong complete or basolateral staining in }> \\
10 \% \text { of tumor cells }\end{array}$ & \\
$\begin{array}{l}\text { Biopsy samples with cohesive IHC } 3+\text { and/or FISH }+ \\
\text { clones (not surgical material) are considered positive } \\
\text { regardless of size; e.g.: }<10 \%\end{array}$ &
\end{tabular}

\section{Results}

The study included a total of 16 patients, including 15 males $(93.8 \%)$ and 1 female $(6.3 \%)$. The mean age of the patients was identified as 61.3 (Table 2). The most common complaint for attending patients was stomach ache with $25 \%$, followed by weight loss and loss of appetite. Metastatic disease was diagnosed in $30 \%$ of the patients using biopsy and imaging methods, and other patients were diagnosed after surgical exploration. The most common site of metastasis was the liver with $31.3 \%$. Concurrent metastasis of the liver and peritoneum was identified in $18.8 \%$ of the patients. The other metastatic sites were the bone and peritone.

Table 2. General characteristics of patients

\begin{tabular}{ccc}
\hline & $\begin{array}{c}\text { Average, Standard } \\
\text { Deviation }\end{array}$ & Median \\
\hline Age & $61,3 \pm 10,1$ & 66 \\
AST $(\mathrm{U} / \mathrm{L})$ & $19.8 \pm 5,6$ & 18 \\
ALT $(\mathrm{U} / \mathrm{L})$ & $19.1 \pm 10.1$ & 19 \\
ALP $(\mathrm{U} / \mathrm{L})$ & $102.9 \pm 28.1$ & 93 \\
$\mathrm{LDH}(\mathrm{U} / \mathrm{L})$ & $241.4 \pm 94.5$ & 196 \\
$\mathrm{WBC}\left(10^{3} / \mathrm{mm}^{3}\right)$ & $5.6 \pm 4.1$ & 5.9 \\
$\mathrm{HGB}\left(\mathrm{g} / \mathrm{dl}^{3}\right)$ & $11.2 \pm 1.4$ & 10.9 \\
$\mathrm{PLT}\left(10^{3} / \mathrm{mm}^{3}\right)$ & $347.3 \pm 157.1$ & 346 \\
\hline
\end{tabular}

ECOG score was 0 in $87.5 \%$ of the patients, and 1 in other patients. The patients underwent 4 cycles of chemotherapy on the average. One patient discontinued chemotherapy due to febrile neutropenia, and 2 patients went into exitus before completing the cycles of chemotherapy. Partial response was achieved in $37.5 \%$ of the patients. The median survival of the patients was found 
as 13.1 months (Figure 1).

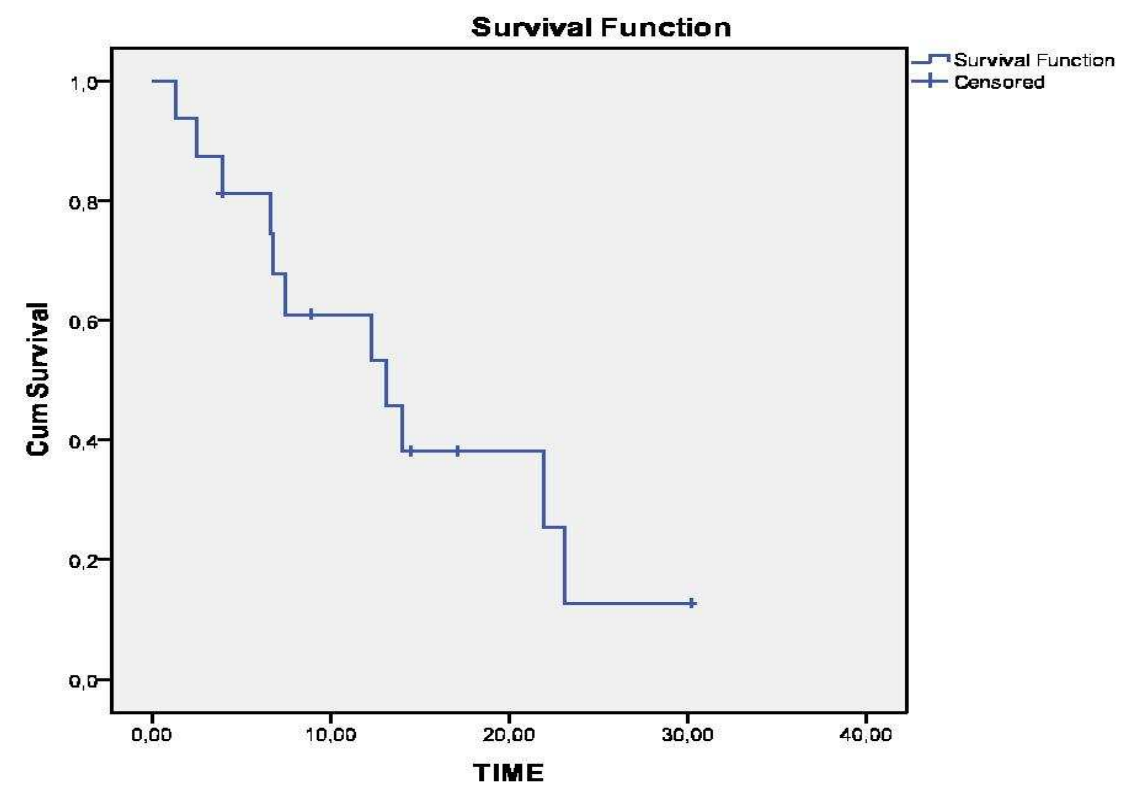

Figure 1. Kaplan-Meier Survival Chart

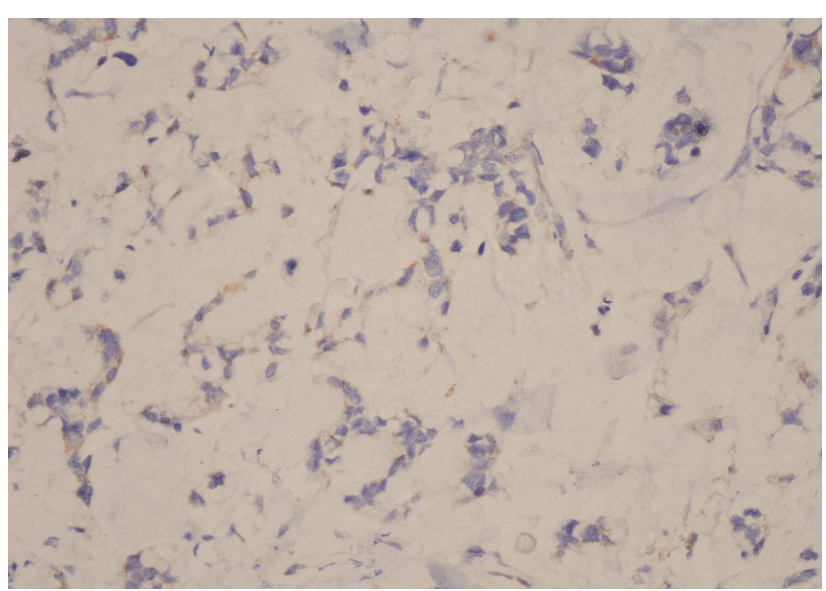

Figure 2. No staining (score 0), HER2 $\times 200$

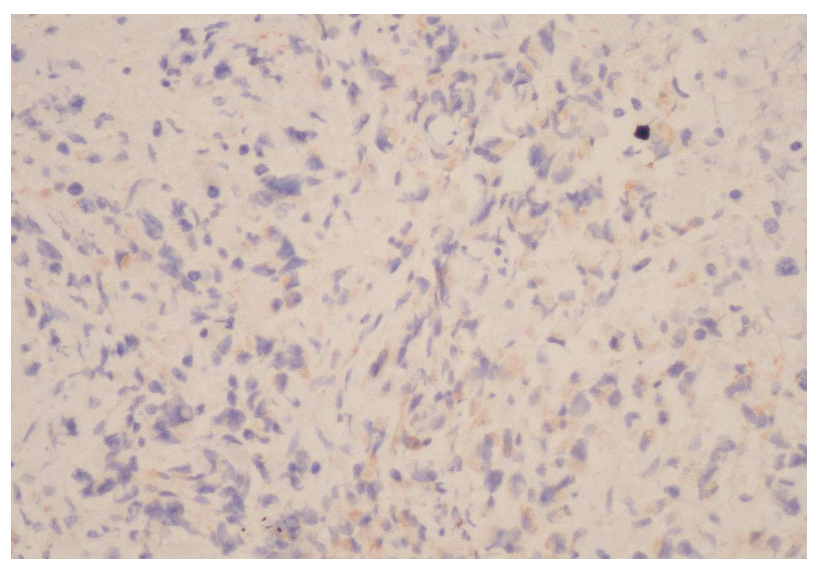

Figure 3. Weak and incomplete membrane staining of tumor cells (score 1+), HER $2 \times 200$

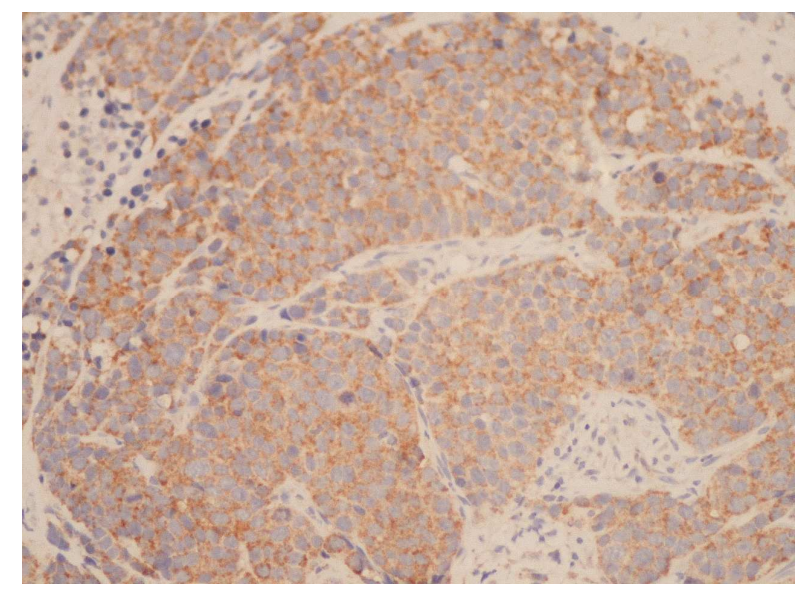

Figure 4. Complete membrane staining at least $10 \%$ of tumor cells, nonuniform and weak intensity (score 2+), HER2 x200

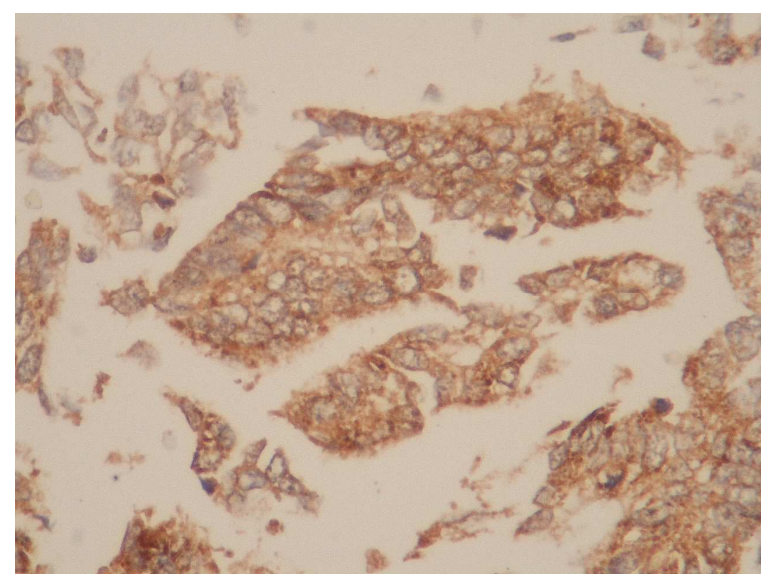

Figure 5. Uniform intense mebrane staining of $>30 \%$ of tumor cells (score 3+), HER $2 \times 400$ 
IHC was found as $0 /$ negative in 4 patients $(25 \%), 1+/$ negative in 5 patients $(31.3 \%), 2+/$ suspected in 4 patients $(25 \%)$, and $3+/$ positive in 3 patients $(18.8 \%)$. (Figure $2-5$ ) As suspected cases were considered as negative, in conclusion, 3 patients $(18.8 \%)$ were considered as her2 positive, and 13 patients $(81.3 \%)$ as negative. Evaluation of the relationship between Her2 expression and the response by chi-square test did not identify a statistical significance, and the $p$ value was found as 0.41. Evaluation of the relationship between Her2 expression and the survival time by long rank test did not yield a statistical significance as well (Figure 6).

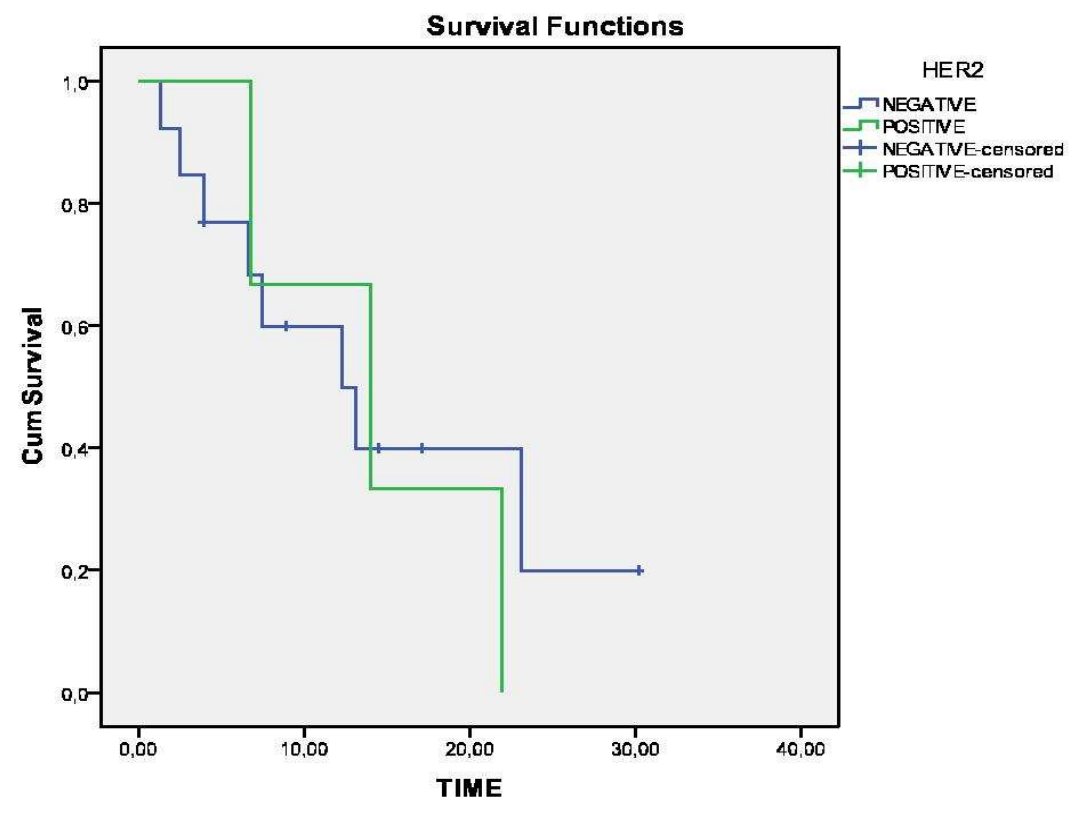

Figure 6. Relationship of Her 2 expression and survival time

\section{Discussion}

Despite early diagnostic and primary prevention efforts, gastric cancer is the second most common reason for exitus in the world [11]. Mucosal resection in the early stage and surgical resection in the local advanced stage are curative treatment methods. Despite adjuvant/neo-adjuvant chemotherapies or chemo-radiotherapies, many patients are lost due to recurrence. In the metastatic phase, the target of treatment is to extent the survival and quality of life. In treatments administered for this reason, it is important to determine which patient will be harmed by the treatment potentially.

In this study, we have identified the HER2 expression ratio in metastatic gastric cancer as $18.8 \%$ by IHC. Yano et al. found this ratio as $27.1 \%$ using FISH method on 200 Japanese patients who underwent surgery for gastric tumor [12]. Tanner et al. identified HER 2 amplification in $12 \%$ of 131 cases of gastric adenocarcinoma using CISH method, and in $24 \%$ of 100 cases with gastroesophageal junction tumor [13].

Our study only used the IHC method and patients who were 2 positive were considered to have negative HER2 expression. It is known that some of the patients with breast cancer, who were 2 positive, had HER2 expression by FISH method. Therefore, HER2 expression ratio may differ from the values we have obtained. The important shortcomings in our study include covering a small number of patients and the use of FISH method.

It is known that HER2 expression is an undesirable prognostic factor in breast cancer. Supportive findings were obtained in studies on gastric cancer. In a retrospective study where 108 cases were evaluated, HER2 overexpression was associated with adverse prognosis [14]. In another study, it was demonstrated that HER positive cases were associated with undesirable prognosis in 22 cases of early stage of gastric cancer with positive HER2 [15]. Nakajima et al. have demonstrated that HER2 positivity is the second most important prognostic factor in early stage gastric cancer, the first being nodal involvement [16].

HER2 overexpression was found to be correlated to lymph node metastasis, distant metastasis and high relapse. It was revealed that patients with HER2 overexpression had a significantly low survival with progression [17].

HER 2 pathway especially plays a role in the repair of DNA damage formed by platin analogues. A synergistic effect is obtained with the combination of treatments aiming Her 2 and chemotherapy [18]. In our study, we have determined that HER 2 expression status does not constitute a statistically meaningful effect in terms of lifetime. Expressions of DNA repair proteins such as excision repair cross-complementing-1 (ERCC1) and breast cancer-1 (BRCA1) are bad prognostic factors for platin based chemotherapies [19]. However, BRCA1 expression demonstrates the docataxel sensitivity [20]. Trastuzumab is 
a fully-humanized monoclonal antibody targeting the HER2 protein by directly binding to its extracellular domain. Majority of Trastuzumab's studies in combination with chemotherapy are combinations without platin based taxan [21].

Chemotherapeutical combination of docetaxel, cisplatin and 5-FU (DCF) is frequently used and effective in local advanced and metastatic gastric cancer. However, the combination has severe adverse effects (9). Two of our patients died during the cycles of chemotherapy. Yıldırım et al have demonstrated that in gastric cancer patients with Bcl-2 expression, the response to DCF chemotherapy was better [22].

We believe that identification of patients who will respond to this treatment may be important to avoid complications. Therefore, we believe that further studies using FISH method with more patients are required to investigate the role of HER2 expression in predicting the response to DCF chemotherapy combination.

\section{References}

[1] Koeppen HK, Wright BD, Burt AD, Quirke P, McNicol AM, Dybdal NO, Sliwkowski MX, Hillan KJ. Overexpression of HER2/neu in solid tumours: an immunohistochemical survey. Histopathology. 2001; 38: 96-104.

[2] Pappas A, Lagoudianakis E, Seretis C, Tsiambas E, Koronakis N, Toutouzas K, Katergiannakis V, Manouras A. Clinical role of HER-2/neu expression in colorectal cancer. J BUON. 2013; 18: 98-104.

[3] Konecny G, Pauletti G, Pegram M, Untch M, Dandekar S, Aguilar Z, Wilson C, Rong HM, Bauerfeind I, Felber M, Wang HJ, Beryt M, Seshadri R, Hepp H, Slamon DJ. Quantitative association between HER-2 / neu and steroid hormone receptors in hormone receptor-positive primary breast cancer. J Natl Cancer Inst. 2003; 95: 142-53.

[4] Owens MA, Horten BC, Da Silva MM. HER2 amplification ratios by fluorescence in situ hybridization and correlation with immunohistochemistry in a cohort of 6556 breast cancer tissues. Clin. Breast Cancer. 2004; 5: 63-9.

[5] Yonemura $\mathrm{Y}$, Ninomiya I, Ohoyama S, Kimura H, Yamaguchi A, Fushida S, Kosaka T, Miwa K, Miyazaki I, Endou Y. Expression of c-erbB-2 protein is an independent indicator of poor short-term prognosis in patients with gastric carcinoma. Cancer. 1991; 67: 2914-8.

[6] Bayrak M, Olmez OF, Kurt E, Cubukcu E, Evrensel T, Kanat O, Manavoglu O. Prognostic significance of c-erbB2 overexpression in patients with metastatic gastric cancer. Clin Transl Oncol. 2013; 15: 307-12.

[7] Park DI, Yun JW, Park JH, Oh SJ, Kim HJ, Cho YK, Sohn CI, Jeon WK, Kim BI, Yoo CH, Son BH, Cho EY, Chae SW, Kim EJ, Sohn JH, Ryu SH, Sepulveda AR. HER2-neu amplification is an independent prognostic factor in gastric cancer. Dig Dis Sci. 2006; 51: 1371-9.

[8] Glimelius B, Ekström K, Hoffman K, Graf W, Sjödén PO, Haglund U, Svensson C, Enander LK, Linné T, Sellström H, Heuman R. Randomized comparison between chemotherapy plus best supportive care with best supportive care in advanced gastric cancer. Ann Oncol. 1997; 8: 163-8.

[9] Van Cutsem E, Moiseyenko VM, Tjulandin S, Majlis A, Constenla M, Boni C, Rodrigues A, Fodor M, Chao Y, Voznyi E, Risse ML, Ajani JA; V325 Study Group. Phase III study of docetaxel and cisplatin plus fluorouracil compared with cisplatin and fluorouracil as first line therapy for advanced gastric cancer: a report of the V325 Study Group. J Clin Oncol. 2006; 24: 4991-7.

[10] Hofmann M, Stoss O, Shi D, Büttner R, van de Vijver M, Kim W, Ochiai A, Rüschoff J, Henkel T. Assessment of a HER2 scoring system for gastric cancer: results from a validation study. Histopathology. 2008; 52: 797-805.

[11] Parkin DM, Bray F, Ferlay J, Pisani P. Global cancer statistics, 2002. CA Cancer J Clin. 2005; 55: 74-108.

[12] Yano T, Doi T, Ohtsu A, Boku N, Hashizume K, Nakanishi M, Ochiai A. Comparison of HER2 gene amplification assessed by fluorescence in situ hybridization and HER2 protein expression assessed by immunohistochemistry in gastric cancer. Oncol Rep. 2006; 15: 65-71.

[13] Tanner M, Hollmén M, Junttila TT, Kapanen AI, Tommola S, Soini Y, Helin H, Salo J, Joensuu H, Sihvo E, Elenius K, Isola J. Amplification of HER-2 in gastric carcinoma: association with Topoisomerase IIalpha gene amplification, intestinal type, poor prognosis and sensitivity to trastuzumab. Ann Oncol. 2005; 16: 273-8.

[14] Uchino S, Tsuda H, Maruyama K, Kinoshita T, Sasako M, Saito T, Kobayashi M, Hirohashi S. Overexpression of cerbB-2 protein in gastric cancer. Its correlation with longterm survival of patients. Cancer. 1993; 72: 3179-84.

[15] Mizutani T, Onda M, Tokunaga A, Yamanaka N, Sugisaki Y. Relationship of c-erbB-2 protein expression and gene amplification to invasion and metastasis in human gastric cancer. Cancer. 1993; 72: 2083-8.

[16] Nakajima M, Sawada H, Yamada Y, Watanabe A, Tatsumi M, Yamashita J, Matsuda M, Sakaguchi T, Hirao T, Nakano H. The prognostic significance of amplification and overexpression of c-met and c-erbB-2 in human gastric carcinomas. Cancer. 1999; 85: 1894-902.

[17] Im SA, Lee KE, Nam E, Kim DY, Lee JH, Han HS, Seoh JY, Park HY, Cho MS, Han WS, Lee SN. Potential prognostic significance of p185(HER2) overexpression with loss of PTEN expression in gastric carcinomas. Tumori. 2005; 91: 513-21.

[18] Boone JJ, Bhosle J, Tilby MJ, Hartley JA, Hochhauser D. Involvement of the HER2 pathway in repair of DNA damage produced by chemotherapeutic agents. Mol Cancer Ther. 2009; 8: 3015-23.

[19] Pietrantonio F, De Braud F, Da Prat V, Perrone F, Pierotti MA, Gariboldi M, Fanetti G, Biondani P, Pellegrinelli A, Bossi I, Di Bartolomeo M. A review on biomarkers for prediction of treatment outcome in gastric cancer. Anticancer Res. 2013; 33: 1257-66.

[20] Wang L, Wei J, Qian X, Yin H, Zhao Y, Yu L, Wang T, Liu B. ERCC1 and BRCA1 mRNA expression levels in metastatic malignant effusions is associated with chemosensitivity to cisplatin and/or docetaxel. BMC Cancer. 2008; 8: 97. 
[21] Gunturu KS, Woo Y, Beaubier N, Remotti HE, Saif MW. Gastric cancer and trastuzumab: first biologic therapy in gastric cancer. Ther Adv Med Oncol. 2013; 5: 143-51.
[22] Yildirim M, Suren D, Goktas S, Dilli UD, Kaya C, Copuroglu R, Yildiz M, Sezer C. The predictive role of Bcl2 expression in operable locally advanced or metastatic gastric carcinoma. J BUON. 2012; 17: 106-9. 